Open Access

\title{
Return to the womb: feminine creative imagery of arghya in a Tantric ritual
}

\author{
Deepak Shimkhada* and Michael Reading
}

\author{
* Correspondence: \\ dshimkhada@gmail.com \\ Claremont School of Theology, \\ Claremont, CA, USA
}

\begin{abstract}
This paper examines the Tantric ritual of the pouring of water from an arghyapatra from cultural, philosophical, and religious perspectives. The authors argue that the range of symbolic meanings within this ritual for multiple reasons goes far beyond its purely physical representation. On the part of the sadhaka there is indeed fertile ground for creatively perceiving the key elements of the ritual, which include water taking on a variety of new and expanded meanings, and the arghyapatra device itself representing the yoni and womb of the Goddess, to which the practitioner attempts a sacred return.
\end{abstract}

\section{Introduction}

Water is an essential element of life, without which no living being may survive. The evidence for water's probiotic nature is manifold and compelling. The first indication of life on our planet is, for instance, said to have occurred within an aquatic environment; that is, in the frothy wellspring of our earth's majestic oceans. The early growth processes of human and animal fetuses, which rely upon the watery and sustaining amniotic fluids of their mothers' wombs for healthy development, also clearly exemplifies water's tremendous life-nurturing capacity. In plant life as well, the role of water as a key ingredient to vegetative growth is evidenced by the fact that wetter climates, such as the rainforest, almost assuredly enjoy an increase in foliage. We can see, then, how in the biological world water is a beneficent force that enables prosperity.

While the importance of water to organism survival may appear self-evident, the notion of it having such exceptional meaning in a religious and spiritual context-as it does certainly within the Hindu tradition-should be a bit more surprising. Yet water is indeed cherished by Hindus with remarkable regularity and zeal. For them water is not only a common substance which may provide practical benefits, but more importantly a magnificent presence which is alive, sublime, and holy. In the Hindu context, water has attained even that rarified status of divinity; and this sort of view is certainly evident in present-day South Asia, where water is frequently equated with the Divine Feminine and designated as a sacred symbol representing both purification and life. It is important to emphasize here how water in the Hindu view is not just sacred but also distinctly feminine as well. One prominent example of this is that, due to the innate connection made between femininity and the life-giving forces of water, rivers in ancient South Asia were personified, rendered female, and then venerated as goddesses (Kinsley 1998). ${ }^{1}$ Our discussion here, which traces many of the cultural and biological 
significances of water within the Hindu perspective, will also outline and explicate the customary offering of arghya (water) to deities at the conclusion of a religious ritual, while lending special attention to how this unfolds and what it means within a Tantric context. ${ }^{2}$

The arghya offering occurs in both the private and public settings. An example of the latter case occurs, for instance, when a large number of people gather at a holy site marked by a kuñda (pool), or tirtha (river, spring, lake)—such as during the Kumbha Melā festival when water is offered with cupped hands to deities after one's taking of a ritual bath (Fig. 1).

The offering of water through an arghyapätra (ritual device, a receptacle designed for holding the arghya), on the other hand, is reserved for a private püjā ceremony (Fig. 2). The symbolic significance of these rituals-in both the public and private contexts alike-can be interpreted as a return to the womb, the womb from which all living beings come into existence.

We argue, then, that the arghyapattra receptacle-fashioned as it is in the shape of a yoni (vulva) - symbolizes deeper ontological and soteriological meanings which find expression within the Tantric context via a sexual symbol of the goddess (Fig. 3). In other words, when a priest or devotee offers the deity water from an arghyapätra (while simultaneously chanting a prescriptive sequence of mantras), the water is being vivified, as it were, as the sustenance and grace-giving amniotic fluid of the goddess, discharged through her yoni (Fig. 4). Likewise, when a worshiper's hands are prayerfully cupped in

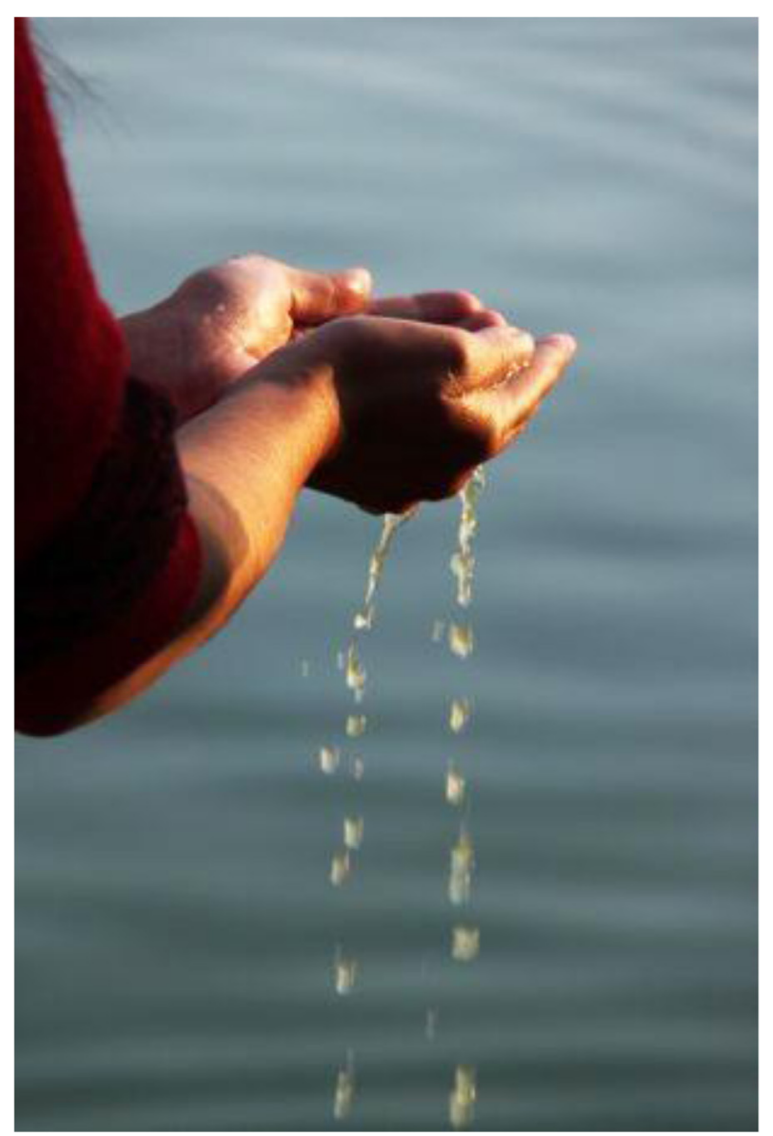

Fig. 1 Oblation of water with cupped hands. Photo: Open Access 


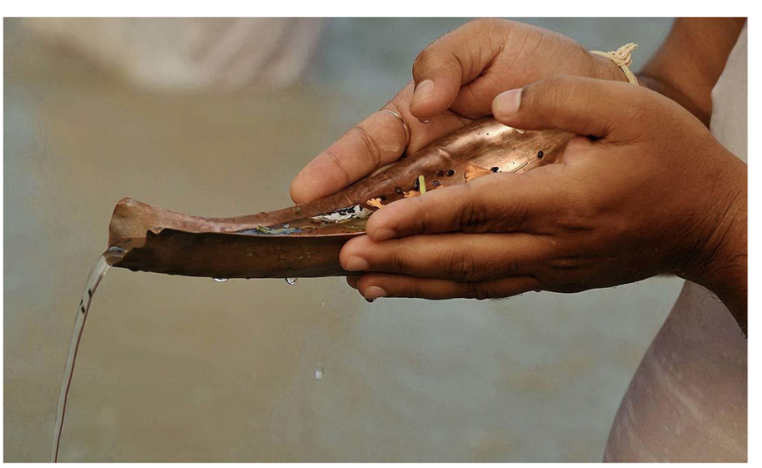

Fig. 2 Oblation of water through an arghyapatra. Photo: Open access

the act of gathering up arghya, the shape which the hands come to form also mimics that of a vulva-and in this sense, the devotee has in another way instantiated the integral presence of the sacred yoni.

Ritually honoring the Hindu gods through this manner of incorporating the most generative forces of nature and biology allows the devotee to transgress such archetypal boundaries as human/nature, male/female, and profane/sacred, into a more holistic and spiritually-cogent union. And lastly, we note that the inclusion of the Divine Feminine in these arghya rituals-as typified by the yoni symbolism, most notably-has for obvious reasons the added potential of being uniquely empowering to female participants.

\section{Ritual scene}

Visualize if you will a devotee sitting down for her or his daily pūjā (worship ritual) inside the püjākotha (shrine) of a private house. The shrine is somewhat secluded and dark; it has one opening to enter through only. The cave-like composition of the worship room itself-though cubed in shape-produces an effect strongly representative of a womb. A poised sādhaka sits in the middle of this room and is appropriately surrounded by her or his accoutrements of ritual objects before performing the daily püja

The devotee first draws upon the floor with white rice powder a sacred diagram of the devī (goddess), which appears as a patterned design of geometrical shapes-triangles, most predominantly (Fig. 5). A small kalașa (water-pot), topped with a coconut, is then placed in the middle of this diagram (Fig. 6). While reciting mantras, the devotee activates the deity symbolized by this water-pot ${ }^{3}$ through offerings of water, flowers, vermillion

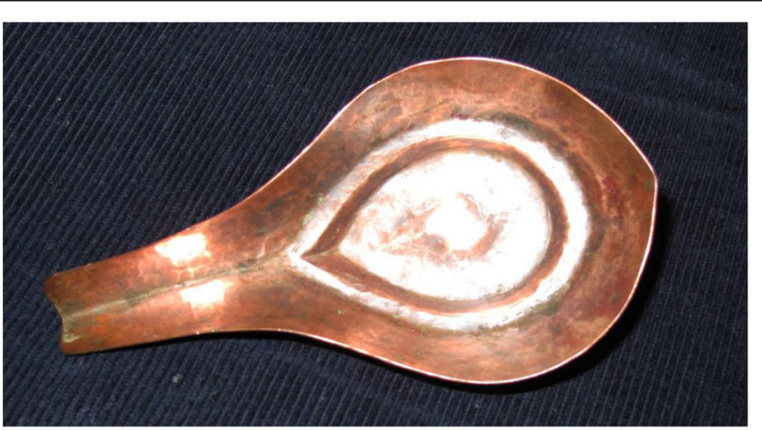

Fig. 3 The personal arghyapatra of Deepak Shimkhada's father. Copper vessel, $20^{\text {th }}$ century. Photo: Deepak Shimkhada 


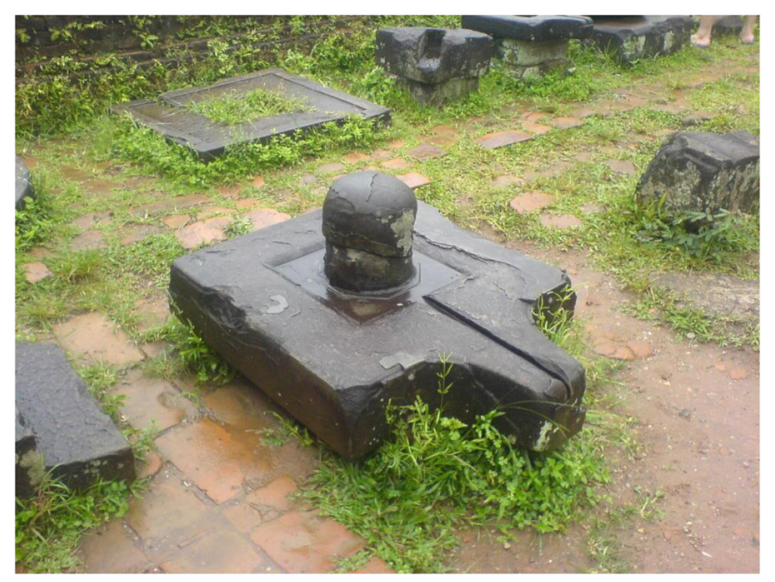

Fig. 4 Shiva-linga with yoni. Photo: Open access

powder, sacred cloth, lamp, morsels of rice, incense, fruits, and cooked sweet dishes. The devotee then beseeches the goddess to descend and take a seat (āvähana) within the diagram called the Sri yañtra (Fig. 6), and she or he accomplishes this by chanting specific mantras for the goddess while also presenting to her one by one the assortment of gathered ritual offerings. As the devotee offers up the various articles which have been, as it were, laboriously assembled beforehand, the devotee intermittently makes meaningful $m \bar{u} d r a \bar{s}$ (hand gestures) and touches various parts of their own body with the intention of sanctifying both the physical and subtle layers of their human constitution. This particular technique, called nyāsa, focuses on placing universal divine energies-which for the Hindu are represented by deity icons-into the body of the devotee through auditory and visual enactments. This is achieved most especially through means of mantra recitation and the envisioning of divinities, with the end ideal being the remarkable blessing of a devotee being internally filled with the deity's sacred presence. This sort of invocative

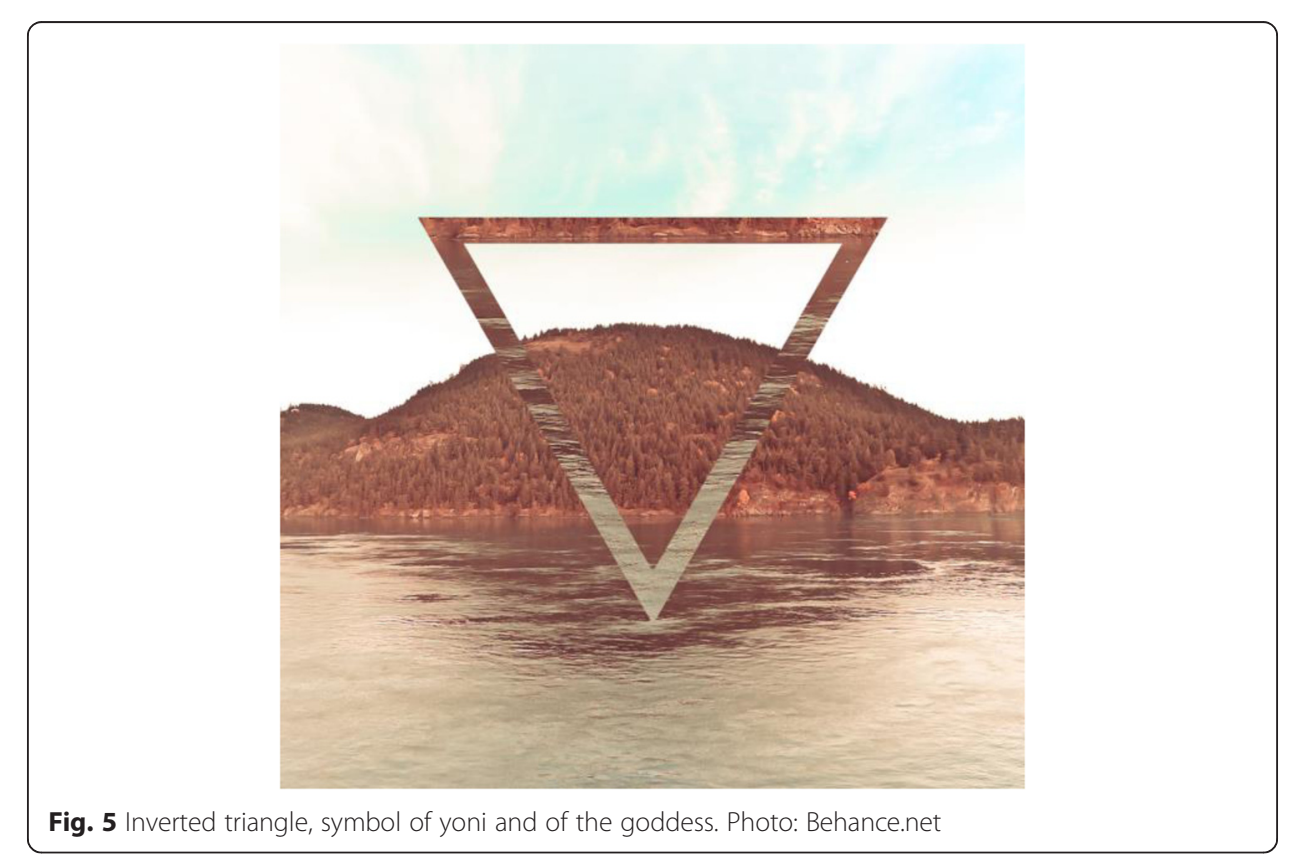




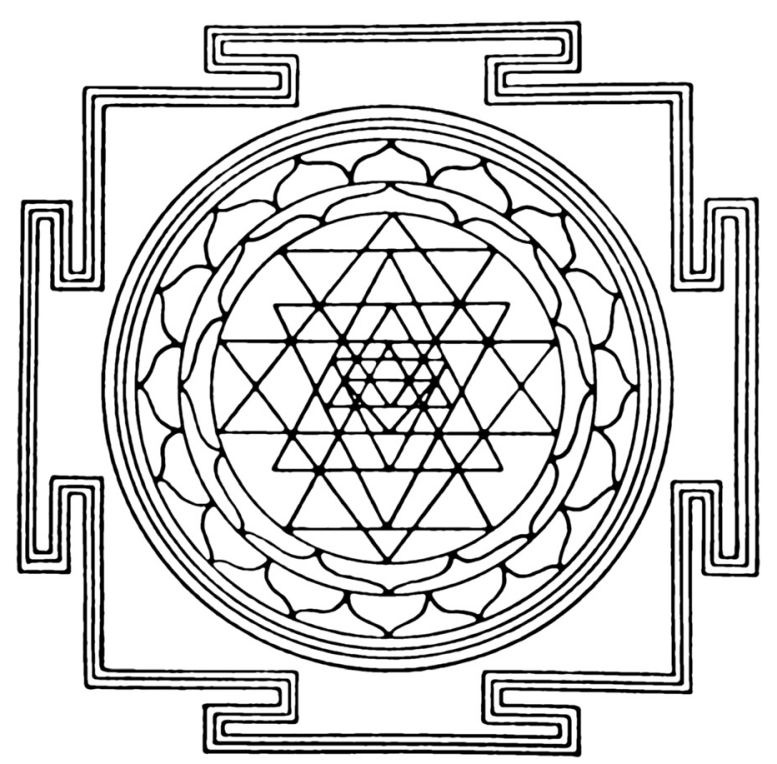

Fig. 6 Sri Yantra, diagram

transference or assimilation of the goddess's divinity is a crucial aspect in terms of actualizing the spiritually transformative aims of the $p \bar{u} j \bar{a}$ ceremony. Lastly, the $p \bar{u} j \bar{a}$ is concluded only when the devotee takes the ritually-consecrated arghyapātra water and pours this substance away.

One of us (Dr. Shimkhada) happens to have a meaningful personal connection to this kind of püjā scene; an example of one of these goddess devotees was in fact my father, who passed away many years ago. I clearly remember how my father rarely allowed anyone into the shrine while performing the $p \bar{u} j \bar{a}$, but that for me he was always ready to make an exception. As I fondly reflect back, I think that this may have been my father's secret wish to impart the knowledge of this ritual or at least develop interest in deity worship through observing his behavior. Another explanation is that as a 10 year old boy who at that time was unenrolled from school, I may have been deemed by my father as 'needing something to do', and hence the perfect candidate for helping run errands and for gathering the daily pūjā articles. Whatever the actual motive may have been, I feel immensely privileged to have had the opportunity to play a part in my father's religious life.

Although my father did not reveal to me the nature or the purpose of his rituals (parts of which are often held to be secret anyway), I now believe, after myself becoming familiarized with some of the classical features of Tantric ritual, that my father was in fact performing a goddess $p \bar{u} j \bar{a}$ and that he was an adherent to the Great Goddess (Mahädevī). What is my reasoning for this assertion? When he performed the pūjē, for instance, I can recall him making various hand gestures (mudrās) and hearing him chant the mantras of the Devi Sukta (Devi 2012). ${ }^{4}$ I also remember seeing him perform nyāsa, the ritual projection of divinities into various parts of his body, and in a manner similar to, in fact, what is described by Mircea Eliade (Eliade 1969) in his seminal book Yoga: Immortality and Freedom.

The disciple "projects" the divinities, at the same time touching various areas of his body; in other words, he homologizes his body with the tantric pantheon, in order to awaken the sacred forces asleep in the flesh itself. Several kinds of nyāsas are 
distinguished, according to their degree of interiorization, for in some cases the divinities and their symbols are "put" into the various organs of the body by a pure act of meditation. ${ }^{5}$

After seeing my father make these nyāsa gestures, he would then offer an oblation of water to the diagram of the goddess from his arghyapātra (Fig. 3). Altogether, my father's exhibited behaviors are indicative of the hallmark Tantric signs of worship as attested by texts such as the Mahānirvāṇa Tantra and the Hastapüjävidhi ${ }^{6}$; and thus, in all likelihood, he was indeed a devotee of the Great Goddess.

\section{Myths behind scientific basis}

As we continue searching for any trace of life amongst the other planets within our solar system, scientists first and foremost look to detect the presence of water, since it is taken to be a reasonable conclusion that without water life cannot exist. The surface of our own planet, the life-abundant Earth, is indeed a robust seventy-percent water, which also mirrors the aquatic proportion to be found within our human bodies. But the centrality of water to life is again by no means a modern scientific discovery; our ancestors were quite privy to this fact long, long ago. And it was they, especially our Hindu ancestors, who managed to first realize the significance of water and hence went on developing various myths about it. Indeed, this is why Heinrich Zimmer (Zimmer 1946) affirms ancient Hindu mythology as being "rich in personifications of the lifegiving power of the waters." Although the breadth of Hindu tradition is indeed replete with references to water and its various associated divinities (whether that be simply to some body of water representing a deity's chosen place of dwelling, or the actual embodiment of the deity itself, usually a goddess), we will here explore just a couple instances, at the exclusion of innumerable others, where such a clear link between water and Hindu mythology has been made.

A particularly provocative myth related to sacred waters is that of Sati's yoni falling off in Kāmākhyā. According to this story, Sati-Śiva's wife, and herself a form of Mahādevī- due to her father's oppressive treatment towards her, decides to commit suicide by jumping into the agnikuñda (sacrificial fire pit). As a result of this tragedy, Siva naturally becomes helplessly distraught as he simply cannot accept that his beloved Sati is now deceased and then, in an expression of severe grief and psychological denial, he begins roaming the earth while carrying the lifeless body of Sati upon his shoulders.

Meanwhile, the various Hindu gods see all this unfolding before them and hold an urgent meeting with one another; being that Siva is also the god of destruction, his present state of affliction is of great concern not only to the gods, but also to the very natural order of the Universe itself. They end up deciding to deploy Viṣnu to carry out an ingenious intervention plan. Viṣnu realizes that Śiva's deplorable state of mind will never resolve itself so long as he continues to carry Sati's corpse and hence is perpetually reminded of his great sorrow. So Viṣnu decides that he must get Siva to relinquish it, but again since Śiva is a powerful god of yoga and destruction, Vișnu wouldn't dare attempt to accomplish that by force. His plan is rather savage but ultimately successful; while a dejected Śiva mournfully wanders the countryside, Viṣnu begins to clandestinely dismember Sati's corpse piece by piece by hacking at it with his weapon in the form of a flaming disk (śudarśana chakra). Eventually, all of Sati's various body parts have fallen 
until absolutely nothing is left of her. According to this legend, Sati's body parts were chopped off at either fifty-one or one-hundred-and-eight locations (depending on one's tradition) of the Indian subcontinent, and all of these locations are now considered to be pițhas, or sacred fords.

Significantly, the place where Sati's yoni is said to have fallen, at least as is stated in The Devī Gìtā, ${ }^{8}$ happens to be in eastern India, in Kāmākhyā, Assam. This site in Kāmākhyā is seen as being especially sacred and auspicious, and is hence marked with a prolific temple. This temple is itself a landmark characterized by its connection with water. And the exact place in which Sati's yoni had purportedly fallen is now marked by the symbol of a yoni on a rock which is located within a natural cave fed by water from a nearby spring. According to legend, the water of the spring turns red every year, and the locals believe this must mean that the goddess is menstruating. This period of cosmic menstruation, as it were, lasts for three days and during this period the doors at the Kāmākhyā temple are closed shut. Some of the reddened water is collected by the head priest in portions of a few drops at a time, and these libations are then absorbed into pieces of cloth for purposes of distribution. These cloth possessions-imbued as they are by the menstrual generativity of the goddess herself-are, of course, reputed as having exceptional, auspicious and magical powers.

This legend, which culminates with the presence and popularity of the Kāmākhyā temple, suggests strongly that the blood which comes from a woman's yoni is of a sacred and pure nature. This sort of message contrasts, then, the more traditional Hindu notion of a woman being in a "polluted" (ritually impure) state during menstruation, and thus during that time being restricted from participation in worship at the temple, püjās, or even within the community amongst gatherings of men. For example, according to Sindhu S. Dange (Dange 1984) in his discussion of the customs laid out in the Bhägavata Pürāna, a pregnant woman should not even "take food that is seen by a woman in menstruation, because women in the period of menstruation are supposed to be in an abnormal condition.." According to the Bhāgavata Pūrāna, women during menstruation have one-fourth of the sin of Brahmahatya attached to them. ${ }^{10}$

The Grhyasütras elaborately describe the rules to be followed by menstrual women, and tend to express a phobic attitude towards their 'polluted' state (Tyagi 2008). ${ }^{11}$ But in the Kāmākhyā temple, and in various other tantric expressions, the converse happens to be true. The menstruating yoni is not to be avoided; instead it is a powerful and healing efflux of the divine feminine. Indeed, this general attitude of reverence towards the sacred feminine-and towards female reproductive agency in particular-represents a familiar perspective within Tantra. In this view, a woman's seclusion during her period does not imply a state of pollution but an opportunity for her to connect to her own fountainhead of innately feminine and divine energy. This more inclusive attitude within Tantra is also further supported by the fact that women themselves are never excluded from yoni worship. Moreover, Tantra proudly acknowledges that this type of yoni worship may in fact be most germane for menstrual women, whose connection to the goddess is naturally accentuated through a likeness of sacred-somatic feminine processes.

It may be important to note here a critical point about Tantra's stance towards sexuality. In spite of popular belief suggesting different, by no means is the central concern of Tantra that of pursuing or optimizing sensual pleasure. Christopher Wallis (Wallis 2012) points out, for instance: "If we survey the Saiva Tantrik literature as a whole, we 
will see that sex per se is virtually absent as a topic...In the original Tantrik sources, we do find some techniques for working with sexual energy and using it to activate kundalini, but we find absolutely no physical techniques aimed at prolonging orgasm and so on." 12 Wallis' larger point here is that, like most other forms of Hindu yoga, Tantra's chief concern is not the garnering of transient pleasures (although it is true that Tantra is not quite as phobic about this, either), but instead with how one ought to obtain spiritual freedom and what the most supreme possibilities are for this kind of quest. So what many fail to realize about Tantra is how in reality it represents a compendium of complex and multifaceted rituals, and is in no sense a manual or tradition about maximizing erotic pleasures.

Tantra does have, however, a legacy of worshiping the dynamic presence of Sakti, the Great Goddess, and Mother of the Universe. Sakti is the creative power that brings all things into being and redeems them back through the process of divinization to Pure Consciousness, or Siva (note: Siva is also symbolically and mythically represented as the consort of Sakti). Wallis (2012) also points out about Sakti that it is "often used to specifically denote spiritual energy, or God's transformative power,"13 which means Shakti is in a sense both a force of transcendence and immanence at once. The emphasis on the creative power of Shakti leads to a veneration of the feminine capacity of lifecreation-and hence the common view of sacrality directed towards the female reproductive organs and processes, since these represent within Tantra the humanly-embodied equivalent of cosmic creation.

In Kathmandu, Nepal-some two thousand miles from Assam, where the Kāmākhyā temple is located-rests another temple named Guhyeswari, which also has a connection with water since the presence of the goddess is there represented by a deep well connected to a spring. As with the Kāmākhyā Temple, in Kathmandu (or Gauhati, more precisely) the goddess has no visible icon, but is instead signified by the natural environs; that is to say, the water itself connotes the presence of the goddess. Fittingly, the word "Guhyeswari" is a composite of two words-guhya and iswari-which, put together, means something akin to "goddess of the secret." It is likewise significant that within Hindu culture the word guhya generally refers also to the secret part of the human body, i.e., the sexual organ (and, of course, the yoni in the case of the goddess). Hence this temple's etymology can be interpreted as signifying the immediate connection which exists between the female yoni and the esoteric nature of the goddess' power.

Both of these temples, then-Kāmākhyā and Guhyeswari together-are frequented and worshipped primarily by Tantrics and Saaktas (followers of Śakti, the Cosmic Divine Feminine). Within these contexts, the open space within each of these temples, similar to that of the arghyapatra receptacle, is again analogous to the concave spaciousness which characterizes the yoni. Although limited in size, these spatial forms represent infinity condensed into a finite space, thereby exemplifying what scholar Harsha Dehejia (Dehejia 2005) calls the "all-important Tantric idea that [it] is through the finite that one reaches the infinite." ${ }^{\text {14 }}$ But the incorporation of water at the Kāmākhyā and Guheyswari temples also makes evident just how intrinsically associated water is to life, and how, in the Tantric view at least, water is even a vital and irreplaceable aspect of the goddess. All in all, for the Tantric devotee water not only represents but also is imbued by feminine divine-energy, and in this sense water is inseparable from the Mahādevī, the Great Goddess herself. 


\section{Fertilizing power of the womb}

We think it not too imaginative of a stretch to suggest that the fertility of our earth's soil is able to maintain its richness in large part due to the very fact that its multitude of organisms not only live but decompose here too. Every single plant and animal is indeed inviolably subjected to the cycle of birth and death, and although perhaps more grim, the second stage of this process at least allows new life-forms to emerge from whatever nutrients a deceased organism has courteously left behind. And this cycle constitutes, of course, the process which allows deserts of lifeless dirt to be wondrously transformed into magnificent gardens of organic possibility. In pondering this curious fact, Hindus have become accustomed to (and appreciative of) this fundamental pattern of fertility and rebirth which continuously replenishes terrestrial soil, and for them it also signifies there being a link between earth's soil and the creative power of the maternal womb.

We would like to now share a prominent Hindu mythological story which accentuates this above connection. There was once a cosmic battle between good and evil, and the antagonist was a prolific demon called Raktabija. This Raktabija had a particularly notorious aptitude for defending himself; he was essentially impregnable to attack since every time his head was chopped off by someone's sword-Durga's, for instance-several more replications of Raktabija were born in his place. So just as the blood droplets caused by Durga's weapon hit the ground, there would appear even more permutations of Raktabija to contend with, until a whole army of separate Raktabijas was formed. ${ }^{15}$ The conclusion to this story came when the gods finally figured out a clever solution; they sent the goddess Kāli out there to give it a shot, and she managed to slay Raktabija by decapitating him while simultaneously sucking his blood dry (for Kälī, this is a gourmet treat) such that no further droplets could reach the ground and regenerate. As Kälī did this, Raktabija's source and vital power was extinguished and the entire matrix of Raktabijas died together and all at once. So though fascinating in and of itself, the relevance of this account to our argument here is that Raktabija's blood obviously had an unusual sort of fecundity to it, but what is even more significant to the purposes of our argument is that his blood became regenerative only once it actually touched the earth. Although the blood of Raktabija was undeniably potent and unique, still the earth was needed to supply that essential procreative womb-energy. We thus feel that this aspect of the popular Raktabija myth exemplifies the Hindu idea of the earth being saturated with distinctly feminine and fertile attributes.

Another example of this earth-womb connection in Hindu thought is the story of Sitäs life as an emergence from (and subsequent return to) the earth. Sitā's birth event was rather unique; she was not born from the womb of a human or from that of a goddess, but is instead said to have emerged from the earth itself. And so if Sitā's nuptial event was indeed a miraculous springing forth from the earth, this would have to mean that the earth itself had acted as the womb for her germination and gestation processes. Here again, the earth is linked in a vital manner to that of procreative potential. It is evident, then, from these two stories and many other such allegories, that the earth in the Hindu view is conceived as a sort of mother whose womb provides life and growth for her precious children, the innumerable creatures of our planet.

Yet, as is certainly true in the case of Sitā's eventual passing, the earth has also associated with it a definite aspect of death, as well. This is certainly the case, for instance, 
when Sïtā asks mother earth to once again open up her womb so that she can be accepted back into its gentle and receptive fold, thus rendering her life a completed circle. In this context, the earth as womb is a place of all three phases of life-creation, preservation and destruction-a bona fide microcosm of the universe. Creation is, after all, dependent upon destruction; and hence destruction is also just as natural and productive as creation itself. And we feel this sort of idea bears evidence in a woman's body rather starkly since her life-giving and watery substances (designed as they are to sustain the life of a potential child within her body) are expelled monthly from the womb when no new beginnings of life have occurred.

There is one final point to consider here. In poor rural communities, where women are commonly subjected to intense field labor and lack access to modern health practices, there is a significantly higher frequency of miscarriages-and this too, we feel, contributes to the characterization of the womb as a grave. This high rate of tragedy is assuredly engraved deep into the psychologies of rural South Asian women (Mahbub ul 2005). ${ }^{16}$ But the presence of death in the womb need not signify weakness, but rather, agency and power. Indeed, the darker side of the feminine, as it were, can be ultimately empowering for women to embrace since it resists portraying the sacred feminine in an overly reductive or romantic manner. Women and goddesses within a Hindu understanding represent at once a twofold nature-nurturing and violent, beautiful and deadly, alluring and strong-and it is all the better that both sides of the coin are to be included.

\section{Sexuality; fluid retention and transgressive approaches}

While water in the Hindu view operates as a viable symbol for sacred and erotic energy, it is also seen as crucial to the chemical constitution of procreative fluids and tissues themselves. In the male human body, for instance, one's seed (semen or retas) is a substance which appears in liquid form, and is thus largely constituted by the presence of water. According to Yoga philosophy-systematized by Patanjali in roughly the early $5^{\text {th }}$ century $\mathrm{CE}$ - there are important spiritual benefits to be gained through one's preservation of sexual fluids, which is accomplished through sustained celibate behavior (brahmacharya).

Although the Tantric tradition offers some differing perspectives and opinions with regards to the usefulness of celibacy, the more general Hindu perspective rather unanimously affirms brahmacharya as an efficacious if not indispensable yogic intention. Significantly, brahmacharya is also considered to be spiritually beneficial for both male and female practitioners alike. The idea is that through a sustained practice of sexual abstinence, one not only remains free of emotional attachment (to one's sexual partner or the sex act itself, for instance), but also accumulates in the body a source of hyper-vital energy, which in the Hindus jargon is termed 'ojas'. So instead of this ojas being wasted, as it were, in the generative replacement of released sexual fluids, it is instead strategically stored up. And this process of storing up ojas, then, is thought by many Hindus to decisively increase one's capacity for liveliness, moral vigor, and spiritual realization.

Given that the retas-ojas paradigm is a more male-specific perspective, a few scholars have queried into whether there is any specific Hindu conception for female sexual fluids to stand in comparison with male semen in terms of vitality and as a substance to be intentionally preserved-and we too feel that this is a fruitful and at least thought-provoking question. But since sexual and generative process in the context of female physiology could easily be seen as more complex and varied in comparison to 
that of their male counterparts, identifying an equivalent to the retas-ojas model has proven to produce no simple or straightforward answer. As a preliminary assertion, Meena Khandelwal (Khandelwal 2004) for instance points to the inherent difficulty in seeking a singular adequate response to this inquiry, explaining how "if semen is the unambiguous focus of a general male physiology, there is no single perspective on the existence of a comparable female substance." ${ }^{17}$ As Khandelwal's hesitancy here suggests, identifying a most essential female fluid to be connected to ojas accumulation is a bit superfluous; for her, the notion of increasing a Hindu woman's spiritual vitality through celibacy is not contingent upon any one singular physiological substance or process, even though in the male context the fluid-conservation aspect plays a rather conspicuous role. When explaining their own self-perceived benefits of brahmacharya, for example, some female Hindu renouncers (sannyāsinis) have pointed not in the direction of bodily vitality but rather to the strong development of psychological freedom that such a practice affords them. ${ }^{18}$ This again represents more of the traditionally ascetic or renunciatory nivrtti stance which has the intention for a sannyāsini to reach an ideal of independence or detachment called 'vairägya', and which allows the practitioner to, in Khandelwal's words, "remain indifferent to illness, pain, loneliness, sensual temptation, material goods, uncertainty, and even insults." 19 The benefits of this kind of nivrtti approach to spirituality are then to be contrasted with the more worldaffirming features and emphases of the pravrtti orientation, to which we will soon return.

Though there remains some ambiguity as to which specific female fluids could be linked to vitality in the context of brahmacharya, suggestions have indeed been posited about key feminine fluids which are thought to contain the vital ojas energy. In her analysis of this question, Wendy O'Flaherty has, for instance, evaluated many such candidates and posits breast milk as being one particularly feasible possibility. ${ }^{20}$ Khandelwal (2004), on the other hand, suggests an altogether different notion for what the female vitality-substance might be, pointing out that the original milk supposition was "later challenged by another theory, which [posited] menstrual (rajas) or uterine (puspa) blood as the female counterpart of semen." ${ }^{21}$ Concerning the former, menstrual blood,Goddess Traditions scholar David Kinsley (Kinsley 1997) has also singled out this substance as being out of any of the possibilities perhaps the most fitting option, reasoning that:

"If menstrual blood is the equivalent of male semen for a woman, then the retention of menstrual blood might also result in spiritual awakening and power. When a woman becomes pregnant, menstrual blood ceases to flow, and the result is dramatically evident: a new being is formed inside her. Another dramatic result of retained blood and pregnancy is the creation of milk. It is as if the blood has been transformed into milk." ${ }^{22}$

Pursuing the matter further, Khandelwal also lists female seed itself-that is to say, either vaginal secretions emitted during the heat of sex, or the seed which is expelled at regular intervals during a woman's period-as possible other sexual fluids which purportedly represent an ample degree of spiritual vitality. ${ }^{23}$ But another key facet to consider here is that, at least in terms of how one actually feels in terms of vitality within their own 
body, the gulf which is said to exist between one's either preservation or loss of sexual fluids may likely be more significant for men than for women. This at least seems to be Khandelwal's suggestion, when she points out how:

Classical and popular conceptions assume that both men and women have power (shakti) to begin with but that women have more. Brahmanic perspectives say that this inequality is intensified through sex, since men lose their power to women, who, by absorbing semen, further increase their own power. ${ }^{24}$

The brahmacharya ideal exemplifies more of the renunciatory emphasis to be commonly found within nivrtti Hindu practices. But as mentioned earlier, this sort of view, of which both Orthodox Hindu spirituality and classical Yoga seem to cherish rather adamantly, contrasts the other more world-affirming (pravrtti) paths, traditions such as Tantra, Kashmir Shaivism, and Shaktism. But what does this latter prav tti spirituality really entail? Arti Dhand (Dhand 2008) explains, for one, how this path is built not upon the principle of exclusion, but pivots rather around the virtues of incorporation and moderation: "The concern of pravrtti dharma, therefore, is not the negation of the body or sexuality, but rather the superintendence of both. The excesses and effects of both need to be tended and restrained." ${ }^{25}$ Also providing a similar rationale for the pravrtti approach is Christopher Wallis (Wallis 2012), who explains as follows:

Desire is, of course, just as divine as anything else, but for it to become a means to liberation, there must be right view toward it. Why would the Tantra bother to legitimate the common variety of delusion-based desire, seeing that it has never brought true and lasting freedom to anyone ? $^{26}$

Thus, in both of these equally legitimate and intriguing contexts-pravrtti and nivrtti-one's respective stance towards sexuality is a most salient feature of one's spirituality at large. And so, getting back to our larger argument here, even though sexuality obviously consists of much more than just sexual fluids, the importance of such fluids either to one's vitality or path of transgressive spirituality should not be understated. And since the reliance of these fluids upon the presence of water is taken as a given, we feel this is another instance in which water has a critical and hence sacred level of functioning within Hindu spirituality.

To speak just a little further about the pravrtti orientation, first consider for a moment how human life is borne into existence through the merging of male and female bodily fluids for the purposes of a miraculous conception. Rahul Peter Das (Das 2003), in his wellresearched book about the origins of life according to ancient Indian texts, explores the nature of procreative bodily fluids which can be demonstrated as clearly contributing to the monumental event of a child being created, and which thereby contain exceptional potency. ${ }^{27}$ Das identifies the same ojas energy which has been introduced here already as also being present in a mother's procreative and fetus-nourishing amniotic fluid within her womb. ${ }^{28}$ In this same work, Das provides evidence suggesting that the relationship between ojas and rasa (in certain cases, at least) as being one and the same thing. Rasa is here understood not in its more normative interpretation of 'liquid'-but rather as 'essence' or, in a more aesthetically-oriented translation, as 'delight'. If we agree with Das' position here, 
we may also be tempted to propose that such fluid-amniotic in this case-is indeed the essence and delight of life. After all, it is indeed with sexual delight culminating in the rapture of an orgasm which constitutes the first step of a life being conceived. And in a similar vein, it is only the human who is fully alive and conscious who is generally able to experience the richer and more aesthetic pleasure that the word rasa in part represents. Thus, we feel it is significant that the word rasa seems to have, as Das suggests, two separate connotations attached to it-both fluidity as well as pleasure.

The general pravrtti or world-affirming approach that conditionally permits, and even in some cases encourages, sexual behavior is closely related to the Tantric idea about the benefit of a practitioner who intentionally embraces polluted substances. The Mahāvidyās (the ten Great Goddesses within Tantric worship), for instance, directly subvert a person's conventional ideas surrounding the avoidance of taboo or forbidden objects and activities through being depicted in their iconography as being engaged in polluted acts and even preferring devotees who are themselves inclined to such transgressive behavior. First to consider here is the Mahāvidyās' association with death—naturally, death in the Hindu view is typically seen as highly unclean and inauspicious, and yet many of the Mahāvidyā goddesses are depicted as sitting upon corpses or hanging around the cremation grounds. ${ }^{29}$ These deities, goddesses such as Kälī and Tara for instance, are commonly portrayed as being covered in blood or as wearing severed heads as ornaments. Second, there is also the depiction of the goddesses as being sexually active and aggressive; the Mahāvidyās, for example, are frequently depicted as having sex themselves or, alternatively, as standing upon a pair of copulating lovers.

David Kinsley's description of Kāli gives a vivid taste of the transgressive, polluted nature of some of the Mahāvidyās, and Tantric Goddesses in general:

Kāli is said to be fierce and black, as her name describes. She stands on the body of Siva in a cremation ground, holding a bloodied cleaver and a severed head; she is naked with disheveled hair and with a garland of skulls as a necklace. She is said to drink wine and is worshiped in a cremation ground, both of which are polluting. Additionally, she is said to be sexually powerful and aggressive, with a vigorous appetite. She has the names 'she whose essential form is sexual desire', she whose form is yoni (vagina)' and 'she who is worshiped with semen. ${ }^{30}$

It is quite easy to conclude from Kinsley's description here how Kāli epitomizes the expression of transgressive behavior which characterizes much of Tantra. And similar to what is found within the Mahāvidyās, there are also some traditions of Tantric worship which explicitly endorse the veneration of the yoni, which represents another instance of intentionally and radically embracing what is otherwise deemed forbidden. Here is a verse written within the Yoni Tantra, for instance, which happens to capture this kind of sentiment:

O Goddess, by the grace of your Yoni I have become the conqueror of death. Day and night I venerate your Yoni, O Great Goddess; ever do I worship Her, O Durga, O Most Beautiful among the Gods, in the lotus of the heart (Niketan and Yoni Tantra 2009). ${ }^{31}$

Though sensational and eye-catching, there is in fact a specific line of reasoning for why such a verse has been written and practiced. Amazzone (2012), for instance, gives one justification for the transgressive Tantric method, explaining that: 
The use of these forbidden substances has a transformative effect on the Yoginis as it helps 'overcome traditional notions of propriety.' Worshipping with 'polluting' substances allows us to embrace negative conceptions of reality and transmute them into their elemental power. ${ }^{32}$

And Amazzone further notes here how erotic invocation has the uniquely valuable ability to summon "the power of [a] woman's yoni and the divine light of passion and love that ignites our will and governs our creative and sexual desires,"33 which is believed to greatly benefit the efforts and zeal of the Tantric practitioner.

Although sexual passion is obviously not representative of all forms of Hindu spirituality-and, as noted earlier, certainly sexuality in this manner is discouraged and suppressed within a great many of its religious orientations-nevertheless it is important to acknowledge how these symbols constitute not just a small niche but a most prevalent brand of Hindu spirituality. This fact becomes all the more evident, Amazzone notes, when traveling to various geographical sites in this region of the world:

Throughout South Asia one finds shrines of natural rock formations or vulvic openings in trees that resemble the yoni. Cleft rocks are smeared with red vermilion powder reminding the devotee of the powerful essence of a woman's menstrual blood and her yoni. Such sacred places hosting a natural form of the yoni have been worshipped for millennia. There are thousands of them. Devotees pay homage to the yoni as the source of all life, the 'womb and tomb' of our existence. ${ }^{34}$

Altogether this geographical reference, the mythology and symbolism of goddesses like Kălī, and scriptures such as the Yoni Tantra, all serve as prime examples of the transgressive nature of Tantric forms of Hindu spirituality. And clearly what these transgressive forms of spirituality show is how not only the notion of purity, but pollution as well, is accepted as a dynamic and powerful lenses through which a yogi may access the Divine Feminine.

So to recapitulate, the overarching point with brahmacharya is that, although perhaps not uniformly expressed, the consummation of sexual desire in both the male and female context has an effect upon the physiological organism which is thought to be sapping to one's vital and spiritual energies. Certain subgroups within Tantrism, however, do assert that sexual behavior as expressed in an entirely free manner without any thought or feeling of personal attachment (and even this, mind you, has traditionally been reserved for elite participants only), would not be subject to any degree of physiological or spiritual ramifications, such as the aforementioned experience of a decrease in vigor. As we have seen in our discussion of pravrtti spirituality, there may indeed be some real and significant credence to this sort of belief. All the same, the hydraulic component which characterizes both male and female sexual fluids only further substantiates our claim that arghya in the Hindu context is, among other things: sacred, generative, and an embodiment of the Divine Feminine. So whether water within sexual fluid is viewed in a Tantric pravrtti context as denoting delight or pleasure, or as a vital substance to be preserved and transmuted in the nivrtti-brahmacharya context, in both instances arghya is itself seen as generative and replenishing. It is these important contexts for water (both as symbol and substance, purity and pollution) which helps establish it as a supremely efficacious offering within the arghyapätra ritual. 


\section{Additional virtues of water with respect to hindu yoga and the human body}

Our discussion of water and its benefits in relation to the human body has mainly so far centered around water's natural ability to augment various biological processes. But for the Hindu, one's body is not purely a process of biology, but also the medium by which a person encounters religious meaning; and in this respect, the presence of water is again equally as advantageous. Take the brain organ, for example. For higher level thinking to occur, the brain can be shown to be dependent upon adequate hydration as a catalyst for spiritual insight. The presence of water, with its unique chemical properties of low viscosity and hyper electro-conductivity, allows the brain to perform its critical functioning as an interpreter of reality and producer of meaning, while also being the 'temple space' through which illuminative insights and spontaneous 'flash of lightning' awakenings may occur.

The process of kundalini awakening ${ }^{35}$-one particularly important such spontaneous awakening — can be similarly demonstrated as being eased by a hydraulic presence, since this too is in large part a bodily phenomenon dependent upon the natural movement of internal electricity and the tolerance of high voltage (albeit focused along the entire spinal cord, rather than just that of the brain). This is all part of a broader statement for Hindus that the human body is in fact and on the most fundamental level pure energy (präna) itself. And considering such an epiphany, it is no great surprise that the intake of water is generally encouraged as a most important consideration for any aspiring practitioner.

In the kundalini experience, water protects all levels or layers (koshas) of the body in a fashion similar to the way nuclear coolant can be shown to neutralize the heat intensity of fusion, and for the yogi this means one's body is through proper hydration prevented from the various perils of overcharge or short-circuiting (a resulting imbalance of somatic energy and insanity are just two of many ways this might negatively manifest for the careless practitioner). ${ }^{36}$ But with respect to the spiritual journey, a person's way of thinking through the limited lens of their own thought constructs (vikalpas) would need ultimately to be sublimated into more of an expansive and liberative form if the desired degree of mental prosperity and freedom is to be attained. Regarding this process of expanding the vikalpas, Wallis writes:

Vikalpas are essentially the distorted and oversimplified stories that we tell ourselves about reality and that we then reify or take as fact. The ability to distinguish that a vikalpa is a representation of reality-and possibly a faulty one-rather than reality itself is a crucial skill for the Tantrik yogī; some say the crucial skill. ${ }^{37}$

But for such vikalpas to reach their higher and more open-ended forms, as well as for a yogi to experience fiery and vigorous insights, there needs to be present a protective and enabling agent of liquidity to allow these mental processes to flourishingly unfold, and again the presence of water can be said to decisively aid us in fulfilling this physiological and yogic need.

Another spiritual benefit of arghya is its undeniable knack for purifying a person's body and mind; that is to say, when humans either touch or immerse ourselves in water, we tend to feel an immediate rush of feeling clean, pure, or renewed. For this reason, and as we have already demonstrated in our larger discussion here, water is frequently incorporated into all different forms of Hindu worship. Concerning this notion, 
Chatterjee (2001) indeed affirms that: "a devout Hindu touches water after every act or stage of puja which is counted as symbolic bath and one is to sip the pavitra or sacred water at every stage of the puja which is a sign of earnestness of intent." ${ }^{38}$

In this sense, the ritual functioning of water constantly purifies and frees the practitioner not just from physical but mental uncleanness, as well. Moreover, in her discussion of the various religious and symbolic meanings of rivers, Anne Feldhaus (Feldhaus 1995) has noted how for many Hindus touching water in the form of a river has the significance of canceling out demerit: "rather, the river, because its water moves, carries the sin away," 39 she explains. So although a majority of humans have experienced water as being a naturally cleansing substance already, after surveying the sum of Hindu ritual in its full panorama of display, we argue that a person would note immediately the remarkable degree to which Hindus have stressed and ritually capitalized upon water and its wondrous and manifold virtues.

Our last consideration with concern to the various merits of arghya is that water plays a crucial role in energetically uniting people with one another. How so? In a lunar and gravitational sense, believe it or not. We posit that the presence of water within our bodies means that we all as living and breathing humans feel the same sort of pull from the moon, the same gravitational vector of force upon us, and this elicits an experiential feeling - again, a type of 'rasa' - which synchronizes us together along the same plane of reality. Every one of us is being, in other words, swayed in a subtle yet nevertheless significant manner depending upon where the moon happens to be located in relation to our aquatic (and thus tidal) bodies.

Perhaps this idea is what compelled Zimmer (1946) to point out once that "the moon is the controller of the waters; and these, circulating through the universe, sustaining all living creatures, are the counterpart on earth of the liquor of heaven, Amrita, the drink of the gods. ${ }^{" 40}$ Considering the multitudinous discordances of our modern global society, for self-evident reasons we suggest that humanity could use all the help it can get in terms of becoming synchronized as one, and the gravitational pull of the moon upon our watery bodies serves as one major boost in this regard. It also provides us with just one further exemplification of the sacred and helpful nature of arghya within the Hindu context.

\section{Conclusion}

Water in the Hindu view elicits a plethora of essential biological functions, undeniably beneficial practicalities, and rich religious meanings. Its presence in South Asian temples and in the exquisite arghyapattra ritual device is meant in various ways to signify the Divine Feminine. Even within the human body itself-the all-important medium through which any spiritual practitioner may experience the sacred-our reliance upon water for higher functioning, vitality, and regenerative processes can hardly be understated. These reasons, among others here unmentioned, form the basis for why Hindus have so adamantly in their history raised water to the status of a divine feminine beingconscious, auspicious, and life-giving. And so the yoni-shaped arghyapattra indeed symbolizes a return to the womb; and the sacred waters which inhabit it will continue to create, replenish, and purify. We conclude with a few lines from astrophysicist Carl Sagan's (Sagan 1980) popular book Cosmos: "The water seems inviting. The ocean calls. Some part of our being knows this is from where we came. We long to return"41 (Fig. 7). 


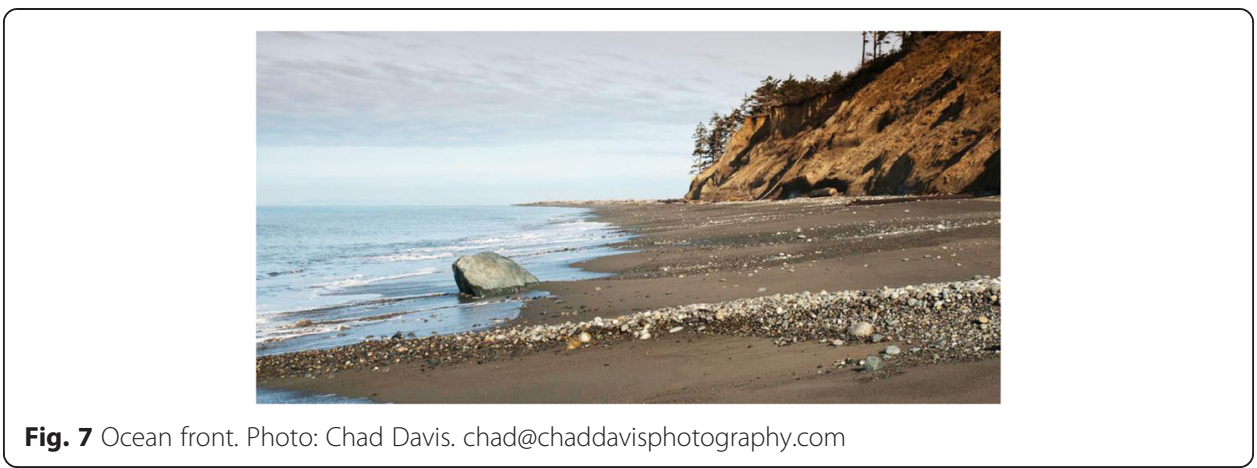

\section{Endnotes}

${ }^{1}$ Zimmer, Heinrich. Myth and Symbols in Indian Art and Civilization. 1972. Pg. 60 David Kinsley, Learning the Story, 231 and Anne Feldhaus, Water and Womanhood (1995).

${ }^{2}$ This paper serves as one portion of a larger project upon which we are currently working. Some of our points here are intended as matters for further discussion. Hence, we gladly invite the reader to share with us whatever reflections and insights may arise.

${ }^{3}$ In Bengal during Durga Puja festival, a kalașa is installed into a ritual scene to symbolize the goddess.

${ }^{4}$ Devi Sukta, Durga Saptasati, Chapter 5.

${ }^{5}$ Mircea Eliade, Yoga: Immortality and Freedom, 210-211. Note: The original source for this comes from the Mahanirvana Tantra, translated by Arthur Avalon under the title Tantra of the Great Liberation, 1913.

${ }^{6}$ Mircea Eliade, op. cit.

${ }^{7}$ Zimmer, Myth and Symbols, 60

${ }^{8}$ The Devī Gìtā, chapter 8, cited by C. Mackenzie Brown. See The Devī Gìtā, The Songs of the Goddess: A Translation, Annotation, and Commentary. Albany, New York: SUNY, 1998, p. 49. For additional accounts regarding the story of the dismemberment of Sati's body, see also D.C. Sircar, The Satka Pithas, Delhi: Motilal Banarsidass, 1973, pp.5-7; Loriliai Biernacki, Renowned Goddess of Desire: Women, Sex, and Speech in Tantra, New York: Oxford University Press, 2007, p. 14.

${ }^{9}$ Dange, The Bhagavata Purana, 92.

${ }^{10}$ Ibid.

${ }^{11}$ Tyagi, Jaya, Engendering the Early Household: Brahmanical Precepts in the Early Grhyasutras Middle of the First Millennium BCE. Delhi: Orient Longman, 2008, p. 198-201.

${ }^{12}$ Wallis, Tantra Illuminated, 41-42

${ }^{13}$ Wallis, Tantra Illuminated, 144

${ }^{14}$ Dehejia, Leaves of a Pipal Tree, 163

${ }^{15}$ Wallis, Tantric Visions, $71-72$

${ }^{16}$ This subject is elaborated by Mahbub ul Haq in his book Human Development in South Asia: The Challenge of Health. New York: Oxford University Press, 2005.

${ }^{17}$ Khandelwal, Sexual Fluids, 166

${ }^{18}$ See Khandelwal's: Women in Ochre Robes

${ }^{19}$ Ibid., 26 
${ }^{20}$ In analyzing O'Flaherty's connection here, Khandelwal suggests even further that: "the analogy between milk (payas) and semen (retas) rests on several criteria. Both are creative and powerful substances. In popular theories of procreation, a father passes important social traits to his child through semen, and a mother passes emotional and intellectual qualities through milk. In mythology, both fluids are capable of independent creation. Both are essences distilled from blood. Both are whitish fluids expressed from a swollen protrusion of the body. And both imply a process or 'outpouring' more than a substance." (Sexual Fluids, 165) Khandelwal's comparison here provides, then, a provocative platform for further research concerning this general conversation surrounding gendered sexual fluids within a framework of Hindu renunciation. For additional discussion into this inquiry, see Khandelwal (2001), O'Flaherty (1980) and Alter (1997).

${ }^{21}$ Khandelwal, Sexual Fluids, 166

${ }^{22}$ Kinsley, Tantric Visions, $160-161$

${ }^{23}$ Khandelwal, Sexual Fluids, 166

${ }^{24}$ Khandelwal, Sexual Fluids, 166

${ }^{25}$ Dhand, Arti, Woman as Fire, Woman as Sage, 159

${ }^{26}$ Wallis, Tantra Illuminated, 81

${ }^{27}$ Rahul Peter Das, The Origin of the Life, Ch. 6

${ }^{28}$ Ibid., 475.

${ }^{29}$ Kinsley, Tantric Visions, 7

${ }^{30}$ Kinsley, Tantric Visions, 80.

${ }^{31}$ Niketan, Yoni Tantra, 2

${ }^{32}$ Amazzone, Goddess Durga, 130

${ }^{33}$ Amazzone, Goddess Durga, 27

${ }^{34}$ Amazzone, Goddess Durga, 27

${ }^{35}$ The somatic dynamics of which are explored in greater detail in Gopi Krishna's Kundalini: The Evolutionary Energy in Man.

${ }^{36}$ For further discussion of this potential hazard, see Lee Sannella's The Kundalini Experience: Transcendence or Psychosis.

${ }^{37}$ Wallis, Tantra Illuminated, 169

${ }^{38}$ Chatterjee, Sacred Hindu Symbols, 44

${ }^{39}$ Feldhaus, Water and Womanhood, 179

${ }^{40}$ Zimmer, Myth and Symbols, 60

${ }^{41}$ Carl Sagan, Cosmos. New York: Random House, 1980, p. 5.

Competing interests

The authors declare that they have no competing interests.

Authors' contributions

All authors co-authored and approved the final manuscript.

Acknowledgement

Dr. LaChelle Schilling, a Ph.D. student of my Divine Feminine in Hinduism course at Claremont Graduate University, read this manuscript in its early stage and provided valuable suggestions for which the authors wish to thank her, and especially for introducing the notion of "womb as a grave."

Received: 24 August 2015 Accepted: 21 October 2015

Published online: 14 November 2015

References

Alter, Joseph. 1997. "Seminal Truth: A Modern Science of Male Celibacy in North India". Medical Anthropological Quarterly 11(3): 275-298. 
Amazzone, Laura. 2012. Goddess Durga and Sacred Female Power. Lanham: Hamilton Books.

Chatterjee, Sanjay. 2001. Sacred Hindu Symbols. New Delhi: Abhinav Publications.

Dange, Sindu S. 1984. The Bhagavata Purana: Mytho-Social Study. New Delhi: Ajanta Publications.

Das, Rahul Peter. 2003. The Origin of the Life of a Human Being: Conception and the Female According to Ancient Indian

Medical and Sexological Literature. Delhi: Motilal Banarsidass.

Dehejia, Harsha. 2005. Leaves of a Pipal Tree; Aesthetic Reflection on Some Hindu Myth and Symbols. Delhi: Motilal Banarasidass.

Devi Suktam from Durga Saptasati_Sanskrit Text with Seven Commentaries. 2012. Revised English Translation, 2 Volumes by F.E. Pargiter. Bharatiya Kala Prakashan.

Dhand, Arti. 2008. Woman as Fire, Woman as Sage; Sexual Ideology in the Mahabhärāta. Albany: SUNY Press.

Eliade, Mircea. 1969. Yoga: Immortality and Freedom. Princeton: Princeton University Press.

Feldhaus, Anne. 1995. Water and Womanhood: Religious Meanings of Rivers in Maharashtra. New York: Oxford University Press Khandelwal, Meena. 2001. "Sexual Fluids, Emotions, Morality: Notes on the Gendering of Brahmacharya.". In Celibacy, Culture, and Society; The Anthropology of Sexual Abstinence, ed. Elisa J. Sobo and Bell Sandra. Madison: University of Wisconsin. Khandelwal, Meena. 2004. Women in Ochre Robes; Gendering Hindu Renunciation. Albany: SUNY Press.

Kinsley, David. 1997. Tantric Visions of the Divine Feminine: The Ten Mahavidyas. Berkeley: University of California Press. Kinsley, David. Learning the Story of the Land. 1998. Purifying the Earthly Body of God; Religion and Ecology in Hindu India. Albany, NY: Edited by Lance Nelson. SUNY Press.

Mahbub ul, Haq. 2005. Human Development in South Asia: The Challenge of Health. New York: Oxford University Press. Niketan, Yoga, Yoni Tantra. Commentary on Selected Verses In Light of Kriya Yoga. New York: Bloomington, 2009. O'Flaherty, Wendy Doniger. 1980. Women, Androgynes, And Other Mythical Beasts. Chicago: University of Chicago Press. Sagan, Carl. 1980. Cosmos. New York: Random House.

Tyagi, Jaya. 2008. Engendering the Early Household: Brahmanical Precepts in the Early Grhyasutras Middle of the First Millenium BCE, 198-201. Delhi: Orient Longman.

Wallis, Christopher. 2012. Tantra Illuminated; The Philosophy, History, and Practice of a Timeless Tradition. Petaluma: Mattamayura Press.

Zimmer, Heinrich. 1946. Myths and Symbols in Indian Art and Civilization. Princeton: Princeton University Press.

\section{Submit your manuscript to a SpringerOpen ${ }^{\circ}$} journal and benefit from:

- Convenient online submission

- Rigorous peer review

- Immediate publication on acceptance

Open access: articles freely available online

- High visibility within the field

- Retaining the copyright to your article 